\title{
FORUM
}

\section{Trophobiosis Between Formicidae and Hemiptera (Sternorrhyncha and Auchenorrhyncha): an Overview}

\author{
JaCQues H.C. Delabie \\ ${ }^{1}$ Lab. Mirmecologia, UPA Convênio CEPLAC/UESC, Centro de Pesquisas do Cacau, CEPLAC, \\ C. postal 7, 45600-000, Itabuna, BA and Depto. Ciências Agrárias e Ambientais, \\ Univ.Estadualde Santa Cruz, 45660-000,Ilhéus, BA, delabie@nuxnet.com.br
}

Neotropical Entomology 30(4): 501-516 (2001)

\begin{abstract}
Trofobiose Entre Formicidae e Hemiptera (Sternorrhyncha e Auchenorrhyncha): Uma Visão Geral
\end{abstract}

\begin{abstract}
RESUMO - Fêz-se uma revisão sobre a relação conhecida como trofobiose e que ocorre de forma convergente entre formigas e diferentes grupos de Hemiptera Sternorrhyncha e Auchenorrhyncha (até então conhecidos como 'Homoptera'). As principais características dos 'Homoptera' e dos Formicidae que favorecem as interações trofobióticas, tais como a excreção de honeydew por insetos sugadores, atendimento por formigas e necessidades fisiológicas dos dois grupos de insetos, são discutidas. Aspectos da sua evolução convergente são apresentados. O sistema mais arcaico não é exatamente trofobiótico, as forrageadoras coletam o honeydew despejado ao acaso na folhagem por indivíduos ou grupos de 'Homoptera' não associados. As relações trofobióticas mais comuns são facultativas, no entanto, esta forma de mutualismo é extremamente diversificada e é responsável por numerosas adaptações fisiológicas, morfológicas ou comportamentais entre os 'Homoptera', em particular Sternorrhyncha. As trofobioses mais diferenciadas são verdadeiras simbioses onde as adaptações mais extremas são observadas do lado dos 'Homoptera'. Ao mesmo tempo, as formigas mostram adaptações comportamentais que resultam de um longo período de coevolução. Considerando-se os insetos sugadores como principais pragas dos cultivos em nível mundial, as implicações das relações trofobióticas são discutidas no contexto das comunidades de insetos em geral, focalizando os problemas que geram em Manejo Integrado de Pragas (MIP), em particular.
\end{abstract}

PALAVRAS-CHAVE: Relações insetos/insetos, relações plantas/insetos, mutualismo, coevolução.

ABSTRACT - In this paper, the mutualistic relationship known as trophobiosis, which occurs convergently between ants and several groups of Hemiptera Sternorrhyncha and Auchenorrhyncha (formerly 'Homoptera') is reviewed. The main characteristics of 'Homoptera' and Formicidae which favor trophobiotic interactions, such as honeydew excretion by sapsucking insects, ant attendance and physiological needs of both insects groups, are discussed. Aspects of the convergent evolution are presented. The most archaic system is not trophobiotic per se, foragers collect the honeydew casually expelled on the foliage by individuals or groups of non-associated 'Homoptera'. The commonest trophobiotic relationships are facultative; therefore, this form of mutualism is extremely diversified and is responsible for a range of physiological, morphological and behavioral adaptations by the 'Homoptera', mainly Sternorrhyncha. The more differentiated trophobioses are true symbioses where the most extreme changes can be observed on the 'Homoptera' side. Meanwhile, the ants show mainly behavioral adaptations resulting from a long coevolutive process. Considering the situation of sap-sucking insects as main crop pests worldwide, implications of trophobiotic relationships are discussed in the context of insect communities, in general, and on the problems that imply to Integrated Pest Management (IPM) in particular.

KEY-WORDS: Insect/insect relationships, plant/insect relationships, mutualism, coevolution. 


\section{Introduction}

Some mutualistic relationships between ants and insects 'Homoptera' are known as trophobiosis, a word derived from the Wasmann's studies (Myers 1928, Hölldobler \& Wilson 1990, Gullan 1997). These relationships have called the attention of many researchers and have been object of a range of publications since the Nineteenth Century. Any attempt to review exhaustively these forms of facultative or obligate associations is condemned to remain fragmentary. The richness of interactions and the quantity of published information, most of it during the last 30 years, and usually restricted to a single pair or a small group of insects, is so numerous and diverse that several volumes would be necessary to condense them. Several reviews are available on this issue (Nixon 1951; Way 1963; Buckley 1987a,b; Sudd 1987; Hölldobler \& Wilson 1990; Gullan 1997). Complementary information, focusing more generally on the relationship of ants with other organisms can be found in Myers (1928), Beattie (1985), Fowler et al. (1991), Jolivet (1996) and Schultz \& McGlynn (2000). I review, hereafter, the current understanding on trophobiotic relationships between the two groups of insects and present some points that I consider of importance as an introduction for further studies on the evolution of these insect/insect interactions.

The trophobiosis which occurs between ants and some 'Homoptera' is not unique, as they are not able to feed on and digest vegetation by themselves. Excluding the fungusgrowing species of the Attini tribe, ants have developed several types of trophobiotic relationships with Lepidoptera larvae of the families Lycaenidae, Riodinidae, and Tortricidae (Maschwitz et al. 1986, Hölldobler \& Wilson 1990, DeVries 1991, Pierce et al. 1991), and Heteroptera species of the families Coreidae, Pentatomidae and Plataspidae (Myers 1928, Maschwitz et al. 1987, Hölldobler \& Wilson 1990, Dejean et al. 2000a, Giberneau \& Dejean 2001). Some 'Homoptera' maintain similar relationships with a range of others insects, in particular Anthribidae, Coccinellidae, Apoidea, and other aculeate Hymenoptera (wasps sensu lato), Tachinidae, Syrphidae and Neuroptera (Belt 1874 In Myers 1928, Auclair 1963, Castro 1974, Kosztarab 1987, Hölldobler \& Wilson 1990, Carver et al. 1991). But it is between ants and the different groups of insects put under the banner 'Homoptera' that this phenomenon has reached its plenitude, at different degrees and with convergent adaptations.

Although still used by North American authors and accepted by most international journals, the term 'Homoptera' is no longer accepted as an order or suborder by hemipteran taxonomists (Carver et al. 1991). Due to the paraphyletic nature of Hemiptera, three suborders are currently recognized: Sternorrhyncha (scale insects, aphids, white flies), Auchenorrhyncha (cicadas, leafhoppers, planthoppers) and Heteroptera (true bugs), with Sternorrhyncha being the sister group of the rest of Hemiptera (Carver et al. 1991). 'Homoptera' is thus an artificial aggregation of both herbivorous Sternorrhyncha and Auchenorrhyncha, and is maintained here for convenience, because of the convergent behaviors in relation to ants observed in both suborders. Nevertheless, as a general rule, the nomenclature of Carver et al. (1991) for the Hemiptera will be followed hereafter.

\section{Who Are the Partners of the Trophobiosis and why Does it Make them so Special?}

'Homoptera' are obligate guests of annual or perennial plants, with different degrees of specialization to their host. As highly specialized herbivores, they are generally regarded as being the worst plant pests worldwide because they remove plant sap, damage the tissues or inject toxins or viruses in many plants of economic importance (Nixon 1951, Carter 1962, Way 1963, Conti 1985, Buckley 1987a, Carver et al. 1991, Gullan 1997, Dejean \& Matile-Ferrero 1996, Dejean et al. 2000a). Many of these pests are not host-specific and neighboring non-cultivated plants may serve as intermediary hosts for the 'Homoptera' and their associated pathogens (Carter 1962, Adenuga \& Adeboyeku 1987). Their more characteristic feature is certainly their mouthpart structure: the Sternorrhyncha and Auchenorrhyncha heads are opisthognathous and their mouth appendices are highly specialized for extraction of plant saps. The mouth parts are modified in a rostrum which secures two pairs of sclerotized and flexible stylets intricated as a tube including salivary and food canals, able to penetrate the most hard plant tissues (Pesson 1944, Auclair 1963, Carver et al. 1991, Dolling 1991). Most of the ant-attended 'Homoptera' feed in plant phloem, except the Cercopidae which feed on xylem (Carter 1962, Carver et al. 1991, Gullan 1997). The exploration of plant tissue by the stylets until reaching a suitable sap source needs several minutes to hours and feeding can also take a long time (Auclair 1963). This mode of exploration of plant sap makes the whole 'Homoptera' species easy prey for predators because the former are unable to withdraw their stylets quickly for escape (Stadler \& Dixon 1998b, 1999). Certainly the relative slowness of these insects for installing or removing their mouthparts whilst feeding may have been one of the stronger determinants of the evolution of myrmecophily in different groups of species.

During exploration of plant tissue by the stylets, a secretion is generally deposited to form a protective feeding track (Carter 1962). The liquid diet depends clearly on the nature of the host plant, but is constituted mainly by nitrogenous components, amino acids, organic acids, amides, carbohydrates and a range of secondary compounds (Auclair 1963). The plant sap is digested through the complex hemipteran digestive system where a part of the gut is closely apposed or encapsulated to another part, constituting an efficient alimentary filter system. This allows the surplus water, sugars and other elements to be eliminated speedily through the hind gut (Pesson 1944, Ammar 1985, Carver et al. 1991). The volume of liquid that passes through the insect body is high and 'Homoptera' needs to excrete large amounts of it while concentrating the nutrients essential to its survival and development. Endosymbionts, intracellular microorganisms found in specialized cells (mycetocystes or bacteriocytes), in organs (mycetomes) or in different tissues, are very diverse and exist in all 'Homoptera'. These supply the insect host with nitrogenous products, amino acids, lipids or vitamins unavailable in the plant sap (Auclair 1963, Miller \& Kosztarab 1979, Houk \& Griffiths 1980, Ammar 1985, Gullan \& Kosztarab 1997, Douglas 1998). With the exception 
of a few families, such as the Diaspididae, most of the Sternorrhyncha and Auchenorrhyncha emit, through the anus, droplets of excreta. This is a sugar-rich liquid known as honeydew. It is derived from the plant sap and partially digested, and mixt with products of the Malpighi tubes, forms a rich and stable nutrient source. The honeydew is a complex mixture of water-soluble carbohydrates (the main proportion, including glucose, sucrose, fructose and others), amino acids, amides, organic acids, alcohol, auxins and salts (Hackman \& Trikojus 1952, Auclair 1963, Way 1963). Honeydew production is extremely variable and has been estimated to be several times the insect body mass per hour (Auclair 1963, Larsen et al. 1992). It is different, qualitatively or quantitatively, depending on whether the aphid is attended by an ant or not, and the type of host plant used (Way 1963, Stadler \& Dixon 1999).

Many Sternorrhyncha and Auchenorrhyncha are gregarious, at least at an early stage of their development. Some remain gregarious until adulthood, such as Aphidoidea, Coccidea, Eurymelidae and Membracidae (Carver et al. 1991). Some Sternorrhyncha have a sedentary lifestyle, such as adult female scale insects, or early in their life cycle (Pesson 1944, Gullan \& Kosztarab 1997). Generally, the first stage of these scale insects, the crawlers, correspond to a dispersion phase when they walk on their own, are carried by ants or are dispersed by wind (Stephens \& Aylor 1978, Washburn \& Washburn 1983). Species that show any form of association with ants, range from 1 to $10-15 \mathrm{~mm}$. Small size, sedentarism, ubiquity and gregarious habits, all contribute to facilitate finding ants, which use them as a stable source of nutrients. On the other hand, the same can be argued to make these insects easy and plentiful hosts for a range of hymenopterous parasites (Carver et al. 1991, Sullivan \& Völk 1999).

Many ants that visit 'Homoptera' are highly opportunistic and have similar feeding characteristics of those visiting plant extrafloral nectaries (if they are not the same species) (Carroll \& Janzen 1973, Wood 1982, Hölldobler \& Wilson 1990, Oliveira \& Brandão 1991, Oliveira \& Pie 1998). Blüthgen et al. (2000) observed that ants which attend 'Homoptera' in the Amazonian forest canopy are generally dominant and monopolize trophobiont exploitation to their own colony, while at extrafloral nectaries sites this is not observed. Furthermore, much of what can be said on obligate or facultative mutualisms between angiosperms and ants apply also to the ant'Homoptera' attendances. Honeydew-producing 'Homoptera' can be seen as an ecological equivalent of plant extrafloral nectaries, and the presence of both ants and sapsucking insects should be understood as a mechanism beneficial to the plant, if trophobiont density remains low (Way 1963, Wood 1982, Cushman \& Addicott 1991). Furthermore, tending of a population of 'Homoptera' warrants ants the permanent access to a honeydew source without depending on seasonal variation of other food production by the host plant (McKey \& Meunier 1996). Nevertheless, evolutionary processes of the two classes of mutualisms are totally independent in all cases, except, as some authors have pointed out, when both systems apparently compete or complete one another (Rico-Gray 1993, Blütghen et al. 2000, Sakata \& Hashimoto 2000).

It now appears clear that ants, as social organisms, had their origin during the Cretaceous age, approximately 100120 million years ago (Johnson et al. 2001). Proto-Hemiptera could be as old as Carboniferous (Evans 1963). With Auchenorrhyncha and Sternorrhyncha much older than ants and known since the Permian or Triassic, the Sternorrhyncha were already common during the Cretaceous (Aphidoidea and Coccoidea), but more diverse in the Tertiary and certainly able to produce honeydew similar to today (Carroll \& Janzen 1973, Miller \& Kosztarab 1979, Gullan \& Kosztarab 1997, Johnson et al. 2001). Nevertheless, true trophobiosis-based relationships between ants and 'Homoptera' certainly appeared in the early Tertiary, since existing Baltic amber fossils suggest an association between aphids and Iridomyrmex in the early Oligocene (Wheeler 1914, Hölldobler \& Wilson 1990), and unambiguous records in Dominican amber of such interactions between ants of the genus Acropyga and Rhizoecinae mealybugs dates to the Miocene (Johnson et al. 2001).

The commonest ant species which attend trophobionts are arboreous, territorial, omnivorous, opportunistically predator or scavenger, and able to provoke a large recruitment of nest congeners on a particular interesting food source. They generally belong to one of the following subfamilies: Dolichoderinae, Formicinae, Myrmicinae (Carroll \& Janzen 1973, Hölldobler \& Wilson 1990), but some cases of attendance by Pseudomyrmecinae (Klein et al. 1992, Gullan 1997) or Ponerinae are also reported. These more primitive ants are generally categorized as solitary hunters or predators and scavengers (Carroll \& Janzen 1973, Hölldobler \& Wilson 1990) but several Neotropical Ponerinae have developed strategies for collecting and carrying liquids to their nests (Weber 1944, Hölldobler \& Wilson 1990). In addition, honeydew collection from Sternorrhyncha or Auchenorrhyncha is reported for a West African Odontomachus (Evans \& Leston 1971) and the Neotropical Odontomachus haematodus (L.) (Myers 1929), Ectatomma tuberculatum (Olivier) (Weber 1946) and Ectatomma sp. (Dietrich \& McKamey 1990). Liquid food is particularly suitable for the more phylogenetically advanced ants, particularly Dolichoderinae and Formicidae (Sudd 1987). It can be easily collected and pre-digested through storage in the crop of foragers or specialized workers (= the "social stomach"). Redistribution occurs easily and fast to the whole society at a low energetic cost through trophallaxis (Hölldobler \& Wilson 1990, Fowler et al. 1991).

Generally, ants that attend Auchenorrhyncha trophobionts are not too "possessive" and several ant species can simultaneously visit a group formed by a single cicadellid, delphacid or membracid species (Larsen et al. 1991, Dejean et al. 1996). The same can be said for a range of Sternorrhyncha for which ants give only discontinuous attention (Way 1963, Adenuga \& Adeboyeku 1987). Nevertheless, cases of specialized trophobiosis, i.e., where a trophobiont group is always attended by the same ant species, are much more common between the Sternorrhyncha, particularly, Coccidae and Pseudococcidae. 


\section{Diversity and Evolution of Mutualisms Between Ants and 'Homoptera'}

Early Stages of 'Homoptera' / Ants Interactions. Almost all Sternorrhyncha and Auchenorrhyncha need to become free from the exceeding honeydew they produce and most of them are not ant-attended or are only accidentally ant-attended. For example, according to Bristow (1991b), only 24\% of aphids on the Rocky Mountains are ant-attended. The physical or mechanical elimination of honeydew is certainly one of the most important problems in 'Homoptera' evolution. The inability to eliminate this excretion can mean the death of sessile species in the short term, by fungi contamination of the plant and animal, or simply by drowning in the liquid (Gullan 1997, Gullan \& Kosztarab 1997). Predators can use honeydew as a chemical signal to locate the sites of feeding sessile or non-sessile species (Bristow 1991b). Aiming to satisfy these exigencies, some scale species produce wax filaments, which isolate the insect body from excretions. Others, envelop these by a hollow tube, several centimeters long in some species, to remove the honeydew as far from the body as they can (Gullan \& Kosztarab 1997). The commonest mechanism by 'Homoptera' able to move is removal by shaking its abdomen in order to throw the honeydew droplet away, as far as possible (Way 1963, Gullan \& Kosztarab 1997) or by kicking it off with the hind leg (Way 1963). In other circumstances, the droplet is eliminated by abdominal contractions or passive elimination by the anus (Way 1963, Gullan 1997). This generally promotes the formation of large spots of the fungus sooty mould (Way 1954, 1963; Carter 1962; Gullan 1997). This is reported sometimes as non-parasitic, sometimes as deleterious, on the foliage where populations of 'Homoptera' occur, where it can reduce the photosynthesis and cover non-ant-attended sap-sucking insects. Consequently, and due to the active foraging activity of numerous ant species on vegetation, the commonest interaction between ants and sap-sucking insects appears to be collection of this dispersed honeydew by ants as they lick directly onto the substrate. No direct contact between the two organisms is established a priori (Hölldobler \& Wilson 1990). Opportunistic ant species, such as those which attend 'Homoptera', are commonly also generalist predators. Simultaneously to honeydew collection on foliage or around the insects, they prey on the sap-sucking insects. An example of this are the ants visiting the pear orchards infested by the Psyllidae Cacopsylla pyricola (Paulson 1998). In fact, interactions between the two groups of insects are reported since Antiquity, as in China (Buckley 1987a, Huang \& Yang 1987) where they were established on the predation ability of ants and gave origin to the first historical applications in biological control.

Facultative Trophobiosis. Most of the best-documented mutualistic relationships between ants and Sternorrhyncha or Auchenorrhyncha draw a true connection between the two organisms and constitute the subsequent evolutionary step. As Stadler \& Dixon (1999) pointed out with aphids, it is likely that any trophobiosis has begun as predator-prey relationship and the ant has been inhibited in its predation by the offering of a droplet of honeydew. Ant-attendance is very common in aphid populations in temperate regions of the Northern hemisphere (Sudd 1987, Bristow 1991b). It is much more diversified in a range of Auchenorryncha and Sternorrhyncha families in tropical regions (Malsch et al. in press) (Table 1). In fact, diverse forms of trophobiosis have evolved independently but in convergent ways in the more diverse families of 'Homoptera' (Table 1). Some of them witness an obligate mutualism, although the larger portion being only facultative or merely opportunistic.

The commonest cases of facultative trophobiosis are found between Sternorrhyncha, possibly as a consequence of the inability to move for many of them (Coccoidea) (Fig. 1), or because of the abundance and quality of the honeydew produced by others (Aphididae). For that reason, it is also between these insects that morphological or behavioral adaptations, destined to facilitate the interactions with ants, are most commonly observed. The obligate ant-attended cicadellid Dalbulus quinquenotatus DeLong \& Nault (MoyaRaygoza \& Nault 2000) produces a larger amount of honeydew than congeneric non-ant attended species, possesses more complex behaviors and is more sessile (nonjumping) than non-attended species (Larsen et al. 1992) According to Dietrich \& McKamey (1990), this sessile behavior observed in different ant-attended Auchenorrhyncha families favors subsociality and gregarious habits.

Following Bristow (1991b), the mutualism is sustained only when costs of maintaining the association are low and benefits are high for both partners. When honeydew is a waste product, mutualism is of low cost for 'Homoptera'. Other costs for both partners are variable and depend of a range of circumstances and situations (Buckley 1987a, Bristow 1991b, Stadler et al. 2001), as described in the following paragraphs.

Ants exploit 'Homoptera' not only for their honeydew, but also as a protein or lipid source when foraging on them as common prey (Nixon 1951; Way 1963; Carroll \& Janzen 1973; Buckley 1987a, b; Sudd 1987; Mckey \& Meunier 1996; Hölldobler \& Wilson 1990; Sakata 1994, 1995; Gullan 1997). Way (1963) explains that ants differentiate between trophobionts and common prey by slow movements of trophobionts which closely look like ant brood movements, while intruders are normally more active or agitated. The "choice" by ants of attending 'Homoptera' found on their territory depends on a range of imbricated factors (see Buckley 1987a) such as: the degree of perturbation of the ants or of the trophobionts (Way 1963); if more than one ant species attends (Sudd 1987, Cushman \& Addicott 1991, Sakata \& Hashimoto 2000); the ant specialization for the attended-insect (Sakata 1994, Gullan 1997); and the lack of proteins in the ant diet, the density or the numerical importance of the group of 'Homoptera' and its ability in producing honeydew, qualitatively and quantitatively (Way 1963; Tilles \& Wood 1982; Delabie et al. 1990; Sakata 1994, 1995; Dejean et al. 2000b).

Generally, the ant solicits release of honeydew by drumming the abdominal extremity of the insect with its antennae or touching it in broad prolonged movements (Nixon 1951, Way 1963, Sudd 1987, Hölldobler \& Wilson 1990, Larsen et al. 1992, Dejean \& Bourgoin 1998). Antennation 
Table 1. Trophobiotic interactions between Formicidae and Hemiptera Auchenorrhyncha and Sternorrhyncha. The references are not a complete review and are only indicative for further research. According to Danièle Matile-Ferrero (pers. comm.), few other families of honeydew-producing Coccoidea are certainly also ant-tended but no information is available in literature.

\begin{tabular}{|c|c|c|c|c|}
\hline Upper classification & Family name & Common name & $\begin{array}{l}\text { Commonness of } \\
\text { trophobiotic } \\
\text { interactions with } \\
\text { ants } \\
\end{array}$ & References \\
\hline \multirow{2}{*}{\multicolumn{5}{|c|}{$\begin{array}{l}\text { Auchenorrhyncha } \\
\text { Cicadomorpha } \\
\text { Cercopoidea }\end{array}$}} \\
\hline & & & & \\
\hline & Cercopidae & $\begin{array}{l}\text { froghoppers, } \\
\text { spittle insects }\end{array}$ & rare & $\begin{array}{l}\text { Dietrich \& McKamey 1990, } \\
\text { Hölldobler \& Wilson } 1990\end{array}$ \\
\hline \multicolumn{5}{|l|}{ Cicadelloidea } \\
\hline & Aetalionidae & $\begin{array}{l}\text { aetalionid } \\
\text { treehoppers }\end{array}$ & $\begin{array}{l}\text { rare, Neotropical } \\
\text { Region }\end{array}$ & $\begin{array}{l}\text { Castro 1975, Brown 1976, } \\
\text { Dejean pers. comm. }\end{array}$ \\
\hline & Cicadellidae & leafhoppers & occasional & $\begin{array}{l}\text { see review in Dietrich \& } \\
\text { McKamey 1990, Carver et al. } \\
\text { 1991, Larsen et al. 1992, } \\
\text { Buckley et al. 1990, Moya- } \\
\text { Raygoza \& Nault 2000, } \\
\text { Michereff Filho pers. comm }\end{array}$ \\
\hline & Eurymelidae & eurymelids & $\begin{array}{l}\text { obligate, Australian } \\
\text { Region }\end{array}$ & $\begin{array}{l}\text { Buckley 1990, Buckley et al. } \\
\text { 1990, Dietrich \& McKamey } \\
\text { 1990, Hölldobler \& Wilson } \\
\text { 1990, Fletcher et al. 1991, } \\
\text { Rozario et al. } 1992\end{array}$ \\
\hline & Membracidae & treehoppers & common & $\begin{array}{l}\text { Myers 1928, Wood 1982, } \\
\text { Bristow 1983, Hölldobler \& } \\
\text { Wilson 1990, Morales } 2000\end{array}$ \\
\hline & Nicomiidae & leafhoppers & rare & Blüthgen et al. 2000 \\
\hline \multicolumn{5}{|l|}{$\begin{array}{l}\text { Fulgoromorpha } \\
\text { Fulgoroidea }\end{array}$} \\
\hline & Cixiidae & $\begin{array}{l}\text { cixiid } \\
\text { planthoppers }\end{array}$ & rare & $\begin{array}{l}\text { Myers 1928, 1929, Dietrich \& } \\
\text { McKamey 1990, Carver et al. } \\
1991\end{array}$ \\
\hline & Delphacidae & delphacid & rare & Myers 1928, Dietrich \& \\
\hline & & planthoppers & (Peregrinus maidis) & $\begin{array}{l}\text { McKamey 1990, Dejean et al. } \\
\text { 1996, Michereff Filho pers. } \\
\text { comm. }\end{array}$ \\
\hline & Derbidae & $\begin{array}{l}\text { derbid } \\
\text { plantohoppers }\end{array}$ & rare & Myers 1928 \\
\hline & Dictyopharidae & $\begin{array}{l}\text { dictyopharid } \\
\text { planthoppers }\end{array}$ & rare & Myers 1928 \\
\hline & Flatidae & flatid planthoppers & $\begin{array}{l}\text { rare and unclear } \\
\text { (Ethiopian Region) }\end{array}$ & Adenuga 1975 \\
\hline & $\begin{array}{l}\text { Fulgoridae } \\
\text { Issidae }\end{array}$ & $\begin{array}{l}\text { lantern flies } \\
\text { issid planthoppers }\end{array}$ & rare & $\begin{array}{l}\text { Hölldobler \& Wilson 1990, } \\
\text { Myers 1928, Dietrich \& }\end{array}$ \\
\hline & & & $\begin{array}{l}\text { (Xestocephalinae, } \\
\text { Australian Region) }\end{array}$ & McKamey 1990 \\
\hline & Tettigometridae & $\begin{array}{l}\text { tettigometrid } \\
\text { planthoppers }\end{array}$ & $\begin{array}{l}\text { rare (Ethiopian } \\
\text { Region) }\end{array}$ & $\begin{array}{l}\text { Myers 1928, Bourgoin 1985, } \\
\text { Dietrich \& McKamey 1990, } \\
\text { Dejean \& Bourgoin 1998, } \\
\text { Dejean et al. 1997, 2000b }\end{array}$ \\
\hline
\end{tabular}


(Table 1. Cont.)

\begin{tabular}{|c|c|c|c|c|}
\hline Upper classification & Family name & Common name & $\begin{array}{l}\text { Commonness of } \\
\text { trophobiotic } \\
\text { interactions with } \\
\text { ants } \\
\end{array}$ & References \\
\hline \multirow{2}{*}{\multicolumn{5}{|c|}{$\begin{array}{l}\text { Sternorrhyncha } \\
\text { Aphidoidea }\end{array}$}} \\
\hline & & & & \\
\hline & Aphididae & aphids & very common & $\begin{array}{l}\text { see reviews in Nixon 1951, Way } \\
\text { 1963, Sudd 1987, Hölldobler \& } \\
\text { Wilson 1990, Bristow 1991b }\end{array}$ \\
\hline \multicolumn{5}{|l|}{ Aleyrodoidea } \\
\hline & Aleyrodidae & whiteflies & rare & $\begin{array}{l}\text { Myers 1928, Carver et al. 1991, } \\
\text { Bastien } 1996\end{array}$ \\
\hline \multicolumn{5}{|l|}{ Coccoidea } \\
\hline & Aclerdidae & aclerdid scales & rare & Smith 1940 in Nixon 1951 \\
\hline & Coccidae & soft scales & very common & $\begin{array}{l}\text { see reviews in Nixon 1951, Way } \\
\text { 1963, Hölldobler \& Wilson } \\
\text { 1990, Gullan } 1997\end{array}$ \\
\hline & Dactylopiidae & cochineal insects & rare & $\begin{array}{l}\text { Webster } 1890 \text { In Hayes } 1920, \\
\frac{\text { www.ru.ac.za/ }}{\text { academic/departments/zootchto/ }} \\
\underline{\text { Martin/dactylopiidae.htm }}\end{array}$ \\
\hline & Diaspididae & armored scales & $\begin{array}{l}\text { rare, association } \\
\text { known only with } \\
\text { Melissotarsus ants } \\
\text { (Ethiopian Region) }\end{array}$ & $\begin{array}{l}\text { see review in Ben-Dov } 1990, \\
\text { see also: Adenuga 1975, Dejean } \\
\& \text { Mony 1991, Fisher \& } \\
\text { Robertson } 1999\end{array}$ \\
\hline & Eriococcidae & felt scales & rare & $\begin{array}{l}\text { Nickerson et al. 1974, Buckley } \\
\text { et al. } 1990\end{array}$ \\
\hline & $\begin{array}{l}\text { Kerriidae } \\
\text { (Lacciferidae) }\end{array}$ & lac scales & rare & $\begin{array}{l}\text { Nixon 1951, Prins et al. } 1975 \text {, } \\
\text { Ben-Dov \& Matile-Ferrero } \\
\text { 1984, Ben-Dov } 1990\end{array}$ \\
\hline & Kermesidae & gall-like coccids & rare & $\begin{array}{l}\text { Ben-Dov \& Matile-Ferrero } \\
\text { 1983, Bullington \& Kosztarab } \\
1985\end{array}$ \\
\hline & Lecanodiaspididae & false pit scales & rare & Lambdin \& Kosztarab 1988 \\
\hline & Margarodidae & giant scales & $\begin{array}{l}\text { (Psoraleococcus, } \\
\text { Australian Region) } \\
\text { rare (Icerya spp.) } \\
\text { and generally } \\
\text { unclear }\end{array}$ & $\begin{array}{l}\text { Nixon 1951, Adenuga 1975, } \\
\text { Campbell 1984, Bigger } 1993\end{array}$ \\
\hline & Pseudococcidae & mealybugs & very common & $\begin{array}{l}\text { see reviews in Nixon } 1951, \text { Way } \\
\text { 1963, Hölldobler \& Wilson } \\
\text { 1990, see also Williams } 1998\end{array}$ \\
\hline & Stictococcidae & hard scale insects & $\begin{array}{l}\text { obligate (Ethiopian } \\
\text { Region) }\end{array}$ & $\begin{array}{l}\text { Nixon 1951; Evans \& Leston } \\
\text { 1971; Adenuga \& Adeboyeku } \\
\text { 1987; Campbell 1984, 1994; } \\
\text { Bigger 1993; Dejean \& Matile- } \\
\text { Ferrero 1996 }\end{array}$ \\
\hline \multicolumn{5}{|l|}{ Psylloidea } \\
\hline & $\begin{array}{l}\text { Psyllidae } \\
\text { (=Chermidae) }\end{array}$ & jumping plant lice & rare & $\begin{array}{l}\text { Myers 1928, Buckley et al. } \\
\text { 1990, Hölldobler \& Wilson } \\
\text { 1990, Dejean et al. 1991, Carver } \\
\text { et al. 1991, Paulson } 1998\end{array}$ \\
\hline
\end{tabular}




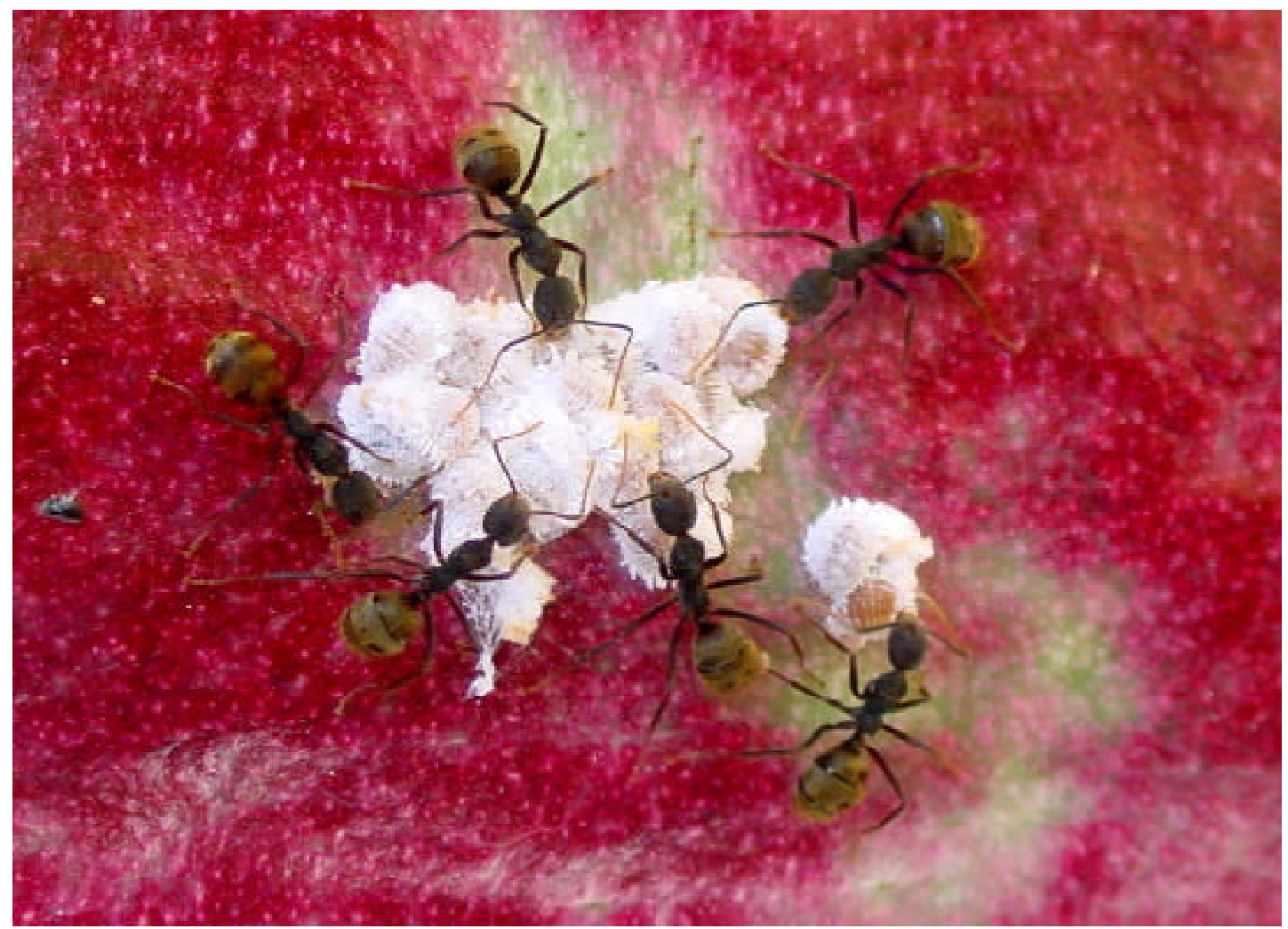

Figure 1. Trophobiosis between Dolichoderus bidens (L.) and the mealybug Planococcus citri (Risso) on a cocoa pod at Bahia, Brazil. (photo: Sébastien Lacau).

continues during the course of honeydew solicitation (Hölldobler \& Wilson 1990, Dejean \& Bourgoin 1998). When honeydew is expelled, the trophobiont keeps the droplet at the abdomen's extremity until an ant removes it (Larsen et al. 1992). But in many cases, the droplet of honeydew is released independently of ant attendance. When this occurs, the fallen honeydew is simply licked by ants (Dejean et al. 1996).

A range of parasitic wasps of several families specialize in attacking isolated or aggregated Sternorrhyncha or Auchenorrhyncha at different stages: Aphelinidae, Braconidae Aphidiinae, Dryinidae, Encyrtidae, Eupelmidae and Mymaridae (Nixon 1951, Nechols \& Seibert 1985, Rozario et al. 1992, González-Hernández et al. 1999, Sullivan \& Völk 1999, Stadler \& Dixon 1999, Moya-Raygoza \& Nault 2000). Beetles of the family Coccinellidae and Syrphidae flies are among their main predators (Way 1963, Collins \& Scott 1982), while spiders have been reported as predators in more recent papers (Cushman \& Whitham 1989, Buckley 1990, Cushman \& Addicott 1991, Moya-Raygoza \& Nault 2000). Therefore, many ant species offer a direct protection to their trophobionts, although this protection is not absolute, since predators and parasites developed sophisticated strategies to avoid ant predation (Way 1963). Indirect benefits are also offered through elimination of dead insects, this behavior contributing to mitigate the rate of parasitism between trophobionts (Buckley 1987a). The motivation of ants in protecting its trophobionts, as estimated by their survival rate, depends mainly on accessibility of the insects, distance to the ant colony, number of individuals in the ant-attended group, trophobiont's ability in aggregating, their capacity in producing honeydew, and diversity of food sources available to the ants (Way 1963, Wood 1982, Delabie et al. 1994, Gullan 1997). In the opinion of Wood (1982), perennial plants provide better sites for ant attendance than annual plants, as these sites are predictable and can be permanently exploited by the ant society. The survival rate of 'Homoptera' also depends on the aggressiveness of its protective ant or whether the attendant ant is dominant (Nixon 1951, Wood 1982, Buckley \& Gullan 1991, Campbell 1994, Gullan 1997). The survival rate does not depend of the number of trophobionts living in the aggregation (Flatt \& Weisser 2000, Morales 2000). In some cases, trophobionts are marked by an ant colonyspecific odor that they can discriminate from conspecifics attended by another ant colony (Schütze \& Maschwitz 1992).

Many ants build a protective shelter, or a tent, made of plant debris, over their aggregations on plant favorable sapsucking sites. These shelters protect their trophobionts against 
parasites or predators, and from the rain incidence. Perhaps, these shelters could also deter non-sessile individuals to escape, such as Membracidae commonly observed on pod peduncles in the Bahian cocoa plantation and "protected" by arborous ants of the genera Azteca, Crematogaster or Dolichoderus (Nixon 1951; Kirkpatrick 1952; Way 1954 1963; Evans \& Leston 1971; Delabie 1990; Dejean et al. 1996; Gullan 1997; Liefke et al. 1998). According to Way (1963), shelters built by ants on their trophobionts derive primarily from similar constructions made by many ants in the aim to protect their trails and resources. Other ants, such as Formica obscuripes Forel, build subterranean galleries to protect their mutualistic aphids that migrate there daily (Seibert 1992). This form of protection is not exclusive to 'Homoptera' as ants build shelters to protect the bugs Caternaultiella rugosa (Plataspidae) in southern Cameroon (Dejean et al. 2000a). For a few ant species, the shelter is an obligate structure for permanent establishment of honeydew-producing insects at the territory periphery of arboreous species, such as Azteca paraensis bondari Borgmeier (Delabie 1990). Ants occasionally tend trophobionts in their own nests, as in the case of subterranean Acropyga and their symbiotic mealybugs tended on the roots of angiosperms (Bünzli 1935, Weber 1944, Delabie et al. 1990), or keep them inside during the winter (Nixon 1951, Seifert 1996, Malsch et al. in press). Arboreous species nest, with their trophobionts, inside silksewed pavilions, as do Malaysian Camponotus and Polyrhachis (Dumpert et al. 1989, Dorow \& Maschwitz 1990, Liefke et al. 1998). Few species nest in hollow internodes of tropical trees or domatias, such as some Azteca associated to Cecropia and Cordia in the Neotropics (Gullan 1997), Camponotus and Crematogaster to Macaranga in Southeast Asia (Maschwitz et al. 1996, Heckroth et al. 1998), Crematogaster to Avicennia in Australian mangroves (Nielsen 1997), and Tetraponera to Gigantochloa bamboo (Klein et al. 1992). Here they tend occasionally or obligatory a population of mealybugs or coccids (see also Gullan et al. 1993, Maschwitz \& Fiala 1995, Gullan 1997, Liefke et al. 1998).

Another important aspect to consider is the case of manipulating, removing or transporting trophobionts to suitable sites by ants (Nixon 1951, Way 1954, Carroll \& Janzen 1973, Delabie et al. 1994, Malsch et al. in press). Crawlers of Coccoidae are able to colonize sites by themselves and are attended later by ants (Nixon 1951; Delabie et al. 1994; Maschwitz et al. 1996, 2000). The choice of a suitable site by an ant can be influenced by several factors, acting individually or collectively such as: a) the place is the most favorable to the production of a high-quality honeydew (like cocoa pods peduncles); b) it is supposedly easier to defend against attacks of predators and parasites of honeydew-producing insects; c) it is easier to strengthen by the construction of shelters; d) it is of easy and quick access to the ants, allowing important economies of time and of the energetic cost of foraging; e) it allows honeydew production of a number of insects enough to compensate cost of exploration by the ants; f) it constitutes a stable and permanent source of food to the ants; and g) it cannot be reached by an ant competitor of the same mosaic.
Obligate Mutualism. A range of morphological, physiological and behavioral adaptations of trophobionts have been attributed to a coevolution with an ant partner. Therefore, some authors (Bristow 1991b, Stadler \& Dixon 1998b) have claimed that obligate mutualism between ants and aphids is rare, and only few species show such adaptations, essentially physiological. According to Way (1963) and Stadler \& Dixon (1998a), a facultative ant-tended aphid has a lowest reproductive and developmental performance when associated to an ant than when not ant-associated. Other authors (Way 1963, Fowler et al. 1991) have suggested the cornicles (or siphunculi, that produce defense or repellent substances to deter aphids enemies) together with the abdomen extremity of aphids as mimicring an ant head offering trophallaxy. In certain aphids, cornicle reduction should be an adaptation to ant attendance (Nixon 1951, Sudd 1987, Schütze \& Maschwitz 1992, Seibert 1992). The soldier caste of aphid Pseudoregma sundanica should compensate the deficiency of ant defense against larger predators (Schültze \& Maschwitz 1991). Others adaptations are presented by some trophobionts. Myzolecaniinae scales live constantly in ant nests and have their spiracles open dorsally, although the normal position of the spiracle is ventral in all other Coccidae (Gullan \& Kosztarab 1997). The Rhizoecini mealybug Neochavesia caldasiae (Balachowsky) pushes strongly with its scorpion tail-like abdomen when refusing to be attended by its mutualistic Acropyga. Setae in the anal region of some mealybugs act as a basket to retain honeydew droplets until ants collect them (Way 1963, Gullan \& Kosztarab 1997). Equivalent structures in ant-associated aphids are called "trophobiotic organ" by Way (1963). The tettigometrid planthopper Euphyonarthex phyllostoma Schmidt attracts the ant's attention when ready to expel a honeydew droplet by raising its body and making an alternate extrusion and withdrawal of the first droplet (Dejean \& Bourgoin 1998). Exocrine glands situated in different regions of the body of this species are responsible for its attractivity to ants (Dejean \& Bourgoin 1998).

True nomadism in Asian ants offer another example of an obligate relationship with 'Homoptera'. Several species of the genus Dolichoderus living in the Malaysian Peninsula are known as herdsmen ants because they spend all their life as nomads, migrating together with symbiotic Allomyrmococcini mealybugs, and occasionally tending some Coccidae or Membracidae (Maschwitz \& Hänel 1985, Hölldobler \& Wilson 1990, Maschwitz \& Dill 1998). The nest of these nomadic ants is established in pre-formed cavities of vegetation where the ants form a compact mass with their own bodies, clinging to one another, and protecting their brood and mealybugs. The ants carry the mealybugs to feeding sites, sometimes far from the colony. Migration is not periodic, as in the case of legionary ants, but depends mainly on exhaustion of homopteran feeding sites. A new nest site depends only on the proximity of suitable sites for the trophobionts establishment (Maschwitz \& Hänel 1985, Hölldobler \& Wilson 1990, Maschwitz \& Dill 1998). In case of danger, mealybugs use a special phoretic mode: climb on the ants or gathered in the ant's mandibles, allowing them to escape quickly. Similar behavior has been reported for the Java mealybug Hippeococcus which is tended by another 
Dolichoderus species (Way 1963, Hölldobler \& Wilson 1990).

Interesting is the case of several genera of the mealybug Rhizoecinae subfamily which shows the oldest reported obligate relationship with Acropyga ants (Formicinae). The hypogeic genera Eumyrmococcus, Neochavesia and Xenococcus are obligatory attended by Acropyga in several parts of the World (Williams 1998). Both ants and mealybugs live on the superficial roots of different plants, in particular coffee and cocoa trees, where this relationship has been largely reported (see Delabie et al. 1990). This mutualism has existed for at least 15-20 million years, with females of the extinct Rhizoecinae genus Electromyrmococcus and Acropyga queens found together, preserved in Miocene Dominican amber (Johnson et al. 2001). In addition, it is well established that female ants carry in their mandibles a female mealybug when undertaking mating flights (Weber 1944, Flanders, 1957, Campos \& Morais 1986, Johnson et al. 2001). This behavior is convergent to that of Attine ants where females disperse and mate carrying a mycelium piece of symbiotic fungus in her infrabuccal pocket (Hölldobler \& Wilson 1990). A similar behavior is known from an arboricolous Pseudomyrmecinae from South-East Asia, Tetraponera binghami (Forel) (formerly T. sp. near attenuata), which lives in hollow internodes of giant bamboo species and carry a mutualistic mealybug during the nuptial flight in her mandibles (Klein et al. 1992). These convergent behaviors warrant successful ant nest foundations only if implementation of the trophobionts is successful. Acropyga tends mealybug eggs together with its own brood in special chambers (Delabie et al. 1990). The ants take care of mealybugs at a suitable site on superficial roots of plants (generally trees) around which the nest is established (Delabie et al. 1990). Similar behavior has been recently described for Malaysian Pseudolasius ants (Malsch et al. in press).

The normal situation for a scale insect is formation by the female of a scale cover, ovisac or wax layers to protect the eggs (Gullan \& Kosztarab 1997), but the Acropyga case illustrates transfer of parental care to the ants. Another case of parental care transfer from trophobiont to ant has been described for the treehopper Publilia reticulata Van Duzee: females abandon facultatively their first brood only if an ant takes care of it; the ants greatly increasing survival probability of the trophobiont's colony (Bristow 1983). In this case, females begin to produce an additional clutch, thus contributing to growth of the treehopper population. In a non ant-attended situation, a single generation per year is produced and females of this and other subsocial species take care of the eggs and young nymphs (Wood 1982, Bristow 1983, Buckley 1987a).

Other spectacular examples of obligate relationship between ants and 'Homoptera' are found in the intertropical regions, such as in Africa, where Gaume et al. (2000) suggested that the female Formicinae Aphomomyrmex afer Emery maintains a double mutualistic relationship with a Leonardoxa legume, and carry associated coccids on it's body during the mating flight. In temperate latitudes, several ant species of Lasius keep aphid eggs in their nests, but only during the winter (Way 1963). According to Dietrich \& McKamey (1990), in many described ant-mutualisms with
Auchenorrhyncha of the Cercopidae, Cixiidae, Issidae, Delphacidae and Tettigometridae families, the trophobionts live inside the ant nest.

In many of these obligate trophobiotic relationships, ants forage in a cloistral manner exclusively on their trophobionts, for example, Acropyga spp. (Johnson et al. 2001) and some Camponotus associated to the palm Korthalsia in Southeast Asia (Mattes et al. 1998). Although having no such confined behavior, herdsmen ants also feed exclusively on their trophobionts, much like the nomad human populations with their stock (Maschwitz \& Hänel 1985, Maschwitz \& Dill 1998).

The Case of the Diaspididae/Ant Mutualism. The case of the armored scales Diaspididae is still not perfectly understood: these scales are unable to liberate honeydew, but only excrete the products of their Malpighi tubes, due to a peculiar anatomical configuration of their gut (Pesson 1944, Gullan \& Kosztarab 1997). Excess products of sap digestion are probably returned via the mouthparts or used in scale shield formation (Gullan \& Kosztarab 1997). Some African Diaspididae are attended by ants of the genus Melissotarsus in very cryptic conditions, the ant nest being completely hidden under the bark of trees. It seems that the ants tend armored scales because of their wax, since these insects are completely naked when ant-attended, while in natural conditions they develop a normal shield (Delage-Darchen $e t$ al. 1972; Prins et al. 1975; Ben-Dov 1978, 1990; Ben-Dov \& Matile-Ferrero 1983). The shield is made by the superposition of several wax covers successively deposited during the scale's developmental stages. Due to their sedentary life, the shield of these scales seems an extremely efficient protection against predacious ants as in the case of Neotropical Acacia-associated Pseudomyrmex (Janzen 1966, in Kosztarab 1987). The aphid Prociphilus fraxini (Fabricius) is densely covered by wax when non ant-tended, while the ants remove the wax if living in association (Way 1963). Several other examples exist of ants removing wax on trophobiotic mealybugs (see Nixon 1951, Way 1963). Diapididae protection is not therefore always so efficient, as attested by reports of ant predation (Ozaki et al. 2000) or suspicion of it (Soares \& Delabie 1999), in research for biological control agents.

\section{Biotic Interactions Around the Ant / 'Homoptera' Niche and Consequences for Integrated Pest Management}

Most of our knowledge about interactions between these two insects groups is obtained from small-scale studies. Other partners involved, directly or indirectly, have been under consideration in only a limited number of papers. Overall interactions inside communities (Fig. 2) have been only occasionally examined as a whole (Gullan 1997, Wimp \& Whitham 2001), except in evaluations on the efficiency of ants that simultaneously tend 'Homoptera' and act as agents of biological control (see for example, Skinner \& Whittaker 1981, González-Hernández et al. 1999). In fact, the most evident true third partner, the plant, has rarely been focused on, with the exception of few recent papers (Buckley 1987a,b; 


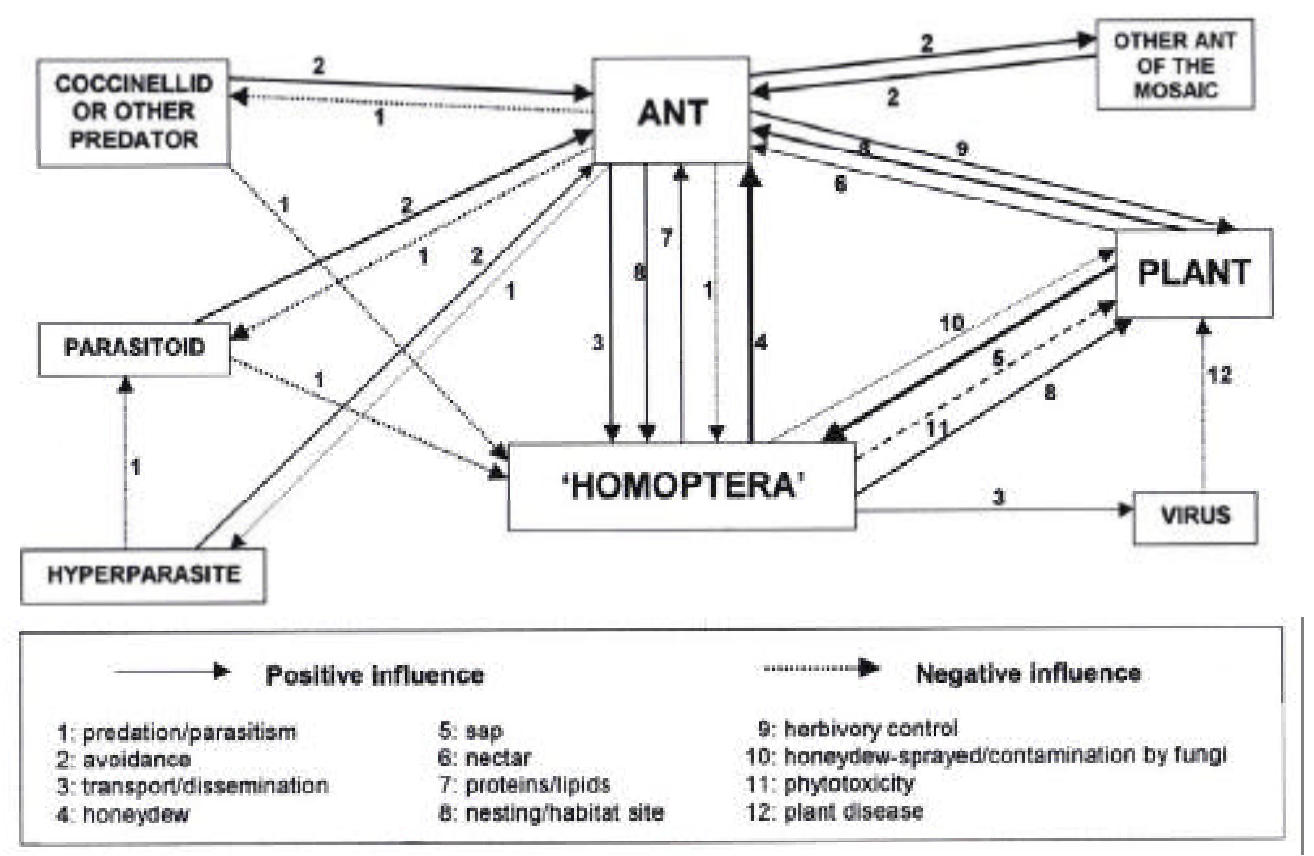

Figure 2. Diagramatic organization of the ant-'Homoptera' community.

Bristow 1991a; Gullan 1997; Gaume et al. 1998). Nevertheless, when the benefits for each of the three partners are evaluated, many authors agree that the plant is highly prejudiced, mainly in monoculture situation, but also in forest management and fruit production (Buckley 1987a,b; Buckley \& Gullan 1991; Dejean \& Matile-Ferrero 1996). Although high costs of maintaining the sap-sucking insect population are evident, the plant receives compensation in the form of ant protection against specialized or opportunistic herbivores (Buckley 1987a, Cushman \& Addicott 1991, Floate \& Whitham 1994, Wimp \& Whitham 2001). Due to the predatory activity of ants over their territory, non ant-attended honeydew producers are consumed (Perfecto \& Sediles 1992, Ozaki et al. 2000). An exhaustive evaluation of the ratio cost/ benefits for the three partners has been made by Buckley (1987a).

Therefore, these three partner's interactions should still be a possible perfect "marriage" if many 'Homoptera' were not also responsible for transmission of plant toxins, fungi pathogens or plant viruses (Carter 1962, Conti 1985). Toxins originate from inoculation of insect salivary substances, which include enzymes and other compounds, produced to allow easy circulation or installation of the stylets near plant vessels and facilitate sap flooding into plant tissues. They provoke local or systemic specific-character malformations, necroses, yellowing and other symptoms (Carter 1962). One of the better-known phytotoxemia, and the worst disease of pineapple, is the pineapple wilt. This disease is provoked worldwide by mealybugs Dysmicoccus brevipes (Cockerell) and D. neobrevipes (Beardsley), and associated in Hawaii to the ant Pheidole megacephala (Fabricius) (Nixon 1951, Carter 1962, González-Hernández et al. 1999).

Many sap-sucking insects are also reservoirs of viruses that they inject into plant tissues together with their saliva.
They act as vectors of these viruses, being responsible for epidemics in many annual crops (Carter 1962). The viruses' nature is highly plant-specific and recently several virus families have been identified, each one using a Sternorrhyncha family as vector (Karasev 2000). The best vectors are found in non-sessile species, and for that reason, many virus problems linked to a 'Homoptera' have aphids as disseminating agents (Carter 1962), regardless of whether ants attend the aphids. One of the worst, and most lethal, viruses is the cocoa swollen shoot. It occurs in cocoa plantations of the Ivory Coast, Ghana, Nigeria, Sierra Leone, and Togo. The pathogen is obligatory disseminated by crawlers of fifteen to twenty mealybug species and their associated ants, primarily Planococcoides njalensis (Laing) (Nixon 1951, Campbell 1974, Dufour 1991, Bigger 1993). Ant-associated mealybugs have also been reported as vectors of other cacao viruses in Trinidad, Sri Lanka and Java (Carter 1962). Other plant diseases, in which the vector is presumed to be an Aphidoidea or Coccidea, have been reported by Nixon (1951).

Many other aspects can be pointed out in insect communities organized around an ant-'Homoptera' association. Ants are able to minimize deleterious effects of fungus disease to their trophobionts (Samways 1983). This is in addition to the advantages mentioned previously of protection against predators and parasites (Way 1963; Collins \& Scott 1982; Buckley 1987a, 1990; Vinson \& Scarborough 1991). In compensation, ants also prey upon a range of hyperparasitoids (Sullivan \& Völk 1999). Some parasites are able to lure the ants by chemical mimicry of their attended aphids (Liepert \& Dettner 1993). Most of the dominant ants that tend 'Homoptera' are also generalist predators and have a strong effect on the different strata of the biota (Way \& Khoo 1992). Furthermore, these ants interact between 
themselves for territory and resources (including sap-sucking insects) (Majer 1993). All these aspects make the community situation very complex (Fig. 2), in particular if an IPM problem is focused on: in such a situation, taking into account plant survival and production, many positive points exist regarding possible benefits to the crop from the presence of ants, but many negative aspects are also experienced. In temperate regions, the situation is generally simpler. Only two or three interactions illustrated happen simultaneously. It can be drastically more confusing in tropical latitudes as several of these interactions commonly coexist. Therefore, any tentative effort at biological control may defy entomologists. It must be kept in mind that tropical ants hate empty spaces. Any control measure applied against an ant could result in its exclusion (maybe) and to its substitution (certainly) by another ant species. The new ant species could arrive together with its cohort of associated species, including trophobionts (which may be worst plant pests than that of their predecessors), plant pathogens, the natural enemies of the trophobionts, their parasites and the parasites of their parasites.

\section{Acknowledgments}

The author is in debt to Antônio Ricardo Panizzi for his invitation and help to edit the manuscript for this section, and with Jonathan D. Majer and, mainly, to Melinda Moir, who made a very helpful revision of the English language. Several researchers provided important information and bibliographic material, in particular: A. Dejean, S. Durou, S. Lacau, P. Gullan, U. Maschwitz, D. Matile-Ferrero, H. Sakata and D. Williams. This paper has been prepared during the author's post-doctoral training at the Federal University of Viçosa (Brazil) under advise of J.E. Serrão. Numerous professors, students and members of the university staff have also contributed with their experience during that period, in particular: D. Amaral, M. Araújo, M. Baptista, M.P. da Costa, T. Della Lucia, M.J. Ferreira, P.S. Fiuza, I.C. Nascimento, J. Lino Neto, I.R. Maldonaldo, M. Michereff Filho, C.A. Neves, L.A. Oliveira Campos, S. Pompolo, F. Salles, E.A. Monteiro da Silva, A. Zaccaro, L. Zinato Carraro, and author's wife, Cléa S.F. Mariano. CNPq projects 52091096-6 and 463452/00-3.

\section{Literature Cited}

Adenuga, A.O. 1975. Mutualistic association between ants and some Homoptera - its significance in cocoa production. Psyche 82: 24-29.

Adenuga, A.O. \& K. Adeboyeku. 1987. Notes on distribution of ant-Homoptera interaction on selected crop plants. Insect Sci. Applic. 8: 239-243.

Ammar, E.-D. 1985. Internal morphology of leafhoppers and planthoppers, 127-162. In L.R. Nault \& J.G. Rodriguez (eds.), The leafhoppers and planthoppers, John Wiley \& Sons, New York, 500p.

Auclair, J. 1963. Aphid feeding and nutrition. Annu. Rev. Entomol. 8: 439-490.
Bastien D. 1996. L'association Philodendrons-FourmisAleurodes. Une étude en Guyane française. D.E.A. Ecologie générale et production végétale, Université Paris 6, I.N.A. Paris-Grignon, 37p.

Beattie, A.J. 1985. The evolutionary ecology of ant-plant mutualisms. Cambridge, University Press, 182p.

Ben-Dov, Y. 1978. Andaspis formicarum n.sp. (Homoptera, Diaspididae) associated with a species of Melissotarsus (Hymenoptera, Formicidae) in South Africa. Insectes Soc. 25: 315-321.

Ben-Dov, Y. 1990. Relationships with ants, p. 339-343, In D. Rosen (ed.). Armored scale insects - their biology, natural enemies and control, vol. A, Elsevier, Amsterdam, $384 \mathrm{p}$.

Ben-Dov, Y. \& D. Matile-Ferreo. 1983. On the association of ants, genus Melissotarsus (Formicidae), with armoured scale insects (Diaspididae) in Africa. Verh. SIEEC X. Budapest, 378-380.

Bigger, M. 1993. Ant-homopteran interactions in a tropical ecosystem. Description of an experiment on cocoa in Ghana. Bull. Entomol. Res. 83: 474-505.

Blüthgen, N., M. Verhaagh, W. Goitia, K. Jaffé, W. Morawetz \& W. Barthlott. 2000. How plants shape the ant community in the Amazonian rainforest canopy: the key role of extrafloral nectarines and homopteran honeydew. Oecologia 125: 229-240.

Bourgoin, T. 1985. Une association méconnue : les Tettigometridae (Hemiptera : Fulgoromorpha) et les fourmis (Hymenoptera : Formicidae). Entomol. Gallica 1: 233-234.

Bristow, C.M. 1983. Treehoppers transfer parental care to ants: a new benefit of mutualism. Science 20: 532533.

Bristow, C.M. 1991a. Are ant-aphid associations a tritrophic interaction?,104-119. Oleander aphids and argentine ants. Oecologia 87: 514-521.

Bristow, C.M. 1991b. Why are so few aphids anttended? In: C.R. Huxley \& D.F. Cutler (eds), Antplant interactions. Oxford University Press, Oxford, $601 \mathrm{p}$.

Brown, R.L. 1976. Behavioral observations on Aethalion reticulatum (Hem., Aethalionidae) and associated ants. Insectes Soc. 23: 99-108.

Buckley, R.C. 1987a. Interactions involving plants, homoptera, and ants. Annu. Rev. Ecol. Syst. 8: 111-135.

Buckley, R.C. 1987b. Ant-plant-homopteran interactions. Adv. Ecol. Res. 16: 53-85. 
Buckley, R.C. 1990. Ants protect tropical Homoptera against nocturnal spider predation. Biotropica 22: 207-209.

Buckley, R. \& P. Gullan. 1991. More aggressive ant species (Hymenoptera: Formicidae) provide better protection for soft scales and mealybugs (Homoptera: Coccidae, Pseudococcidae). Biotropica 23: 282-286.

Buckley, R., P. Gullan, M.J. Fletcher \& R.W. Taylor. 1990. New ant homopteran interactions from tropical Australia. Aust. Entomol. Mag. 17: 57-60.

Bullington, S.W. \& M. Kosztarab, 1985. Revision of the family Kermesidae (Homoptera) in the Nearctic Region based on adult and third instar females. Bul., Virginia Polytech. Inst. St. Univ. 85: 1-118.

Bünzli, G.H. 1935. Untersuchungen über coccidophile Ameisen aus den Kaffeefeldern von Surinam. Mitt. Schweiz. Ent. Ges. 16: 453-593.

Campbell, C.A.M. 1974. The distribution of mealybug vectors of CSSV within trees. Proc. $4^{\text {th }}$ Conf. Western African Cocoa Entomologists. Legon, Ghana, 1974, 6771.

Campbell, C.A.M. 1984. The influence of overhead shade and fertilizers on the Homoptera of mature UpperAmazon coca trees in Ghana. Bull. Entomol. Res. 74: 163-174.

Campbell, C.A.M. 1994. Homoptera associated with the ants Crematogaster clariventris, Pheidole meacephala and Tetramorium aculeatum (Hymenoptera: Formicidae) on cocoa in Ghana. Bull. Entomol. Res. 84: 313-318.

Campos, L.A. de O. \& Morais, H.C. 1986. Transporte de homópteros por fêmeas de formigas do gênero Acropyga (Formicinae) em Viçosa, MG. Anais do VII Encontro de Mirmecologia do Estado de São Paulo, F.H.Caetano ed. Unesp-Fapesp-CNPq, 52-53.

Carroll, C.R. \& D.H. Janzen. 1973. Ecology of foraging by ants. Annu. Rev. Ecol. Systematics 4: 231-257.

Carter, W. 1962. Insects in relation to plant disease $\left(2^{\text {nd }}\right.$ edition). John Wiley \& Sons, New York, 705p.

Carver, M., G.F. Gross \& T.E. Woodward. 1991. 30Hemiptera, p. 429-515, CSIRO. The insects of Australia. Cornell Univerity Press, Ithaca, New York, 542p.

Castro, P.R.C. 1975. Mutualismo entre Trigona spinipes (Fabricius, 1793) e Aethalion reticulatum (L. 1767) em Cajanus indicus Spreng. na presença de Camponotus spp. Ci. Cult. 27: 537-539.

Collins, L. \& J.K. Scott. 1982. Interaction of ants, predators and the scale insect, Pulvinariella mesembryanthemi, on Carpobrotus edulis, an exotic plant naturalized in western
Australia. Aust. Entomol. Mag. 8: 73-78.

Conti, M. 1985. Transmission of plant viruses by leafhoppers and planthoppers, p. 289-307. In L.R. Nault \& J.G. Rodriguez (eds.), The leafhoppers and planthoppers, John Wiley \& Sons, New York, 500p.

Cushman, J.H. \& J.F. Addicott. 1991. Conditional interactions in ant-plant-herbivore mutualisms, p. 92-103. In C.R. Huxley \& D.F. Cutler (eds), Ant-plant interactions. Oxford University Press, Oxford, 601p.

Cushman, J.H. \& T.G. Whitham. 1989. Conditional mutualism in a membracid-ant association: temporal, agespecific, and densitu-dependent effects. Ecology 70: 1040-1047.

Dejean, A., B. Nkongmeneck, B. Corbara \& C. DjietoLordon. 1991. Impact des fourmis arboricoles sur une pullulation d'Achaea catocaloides (Lepidoptera, Noctuidae) dans des plantations de cacaoyers du Cameroun. Acta Oecologica 12: 471-488.

Dejean, A. \& D. Matile-Ferrero. 1996. How a grounddwelling forest ant species favors the proliferation of an endemic scale insect (Hymenoptera: Formicidae; Homoptera: Stictococcidae). Sociobiology 28: 183-195.

Dejean, A., M. Gibernau \& T. Bourgoin. 2000a. A new case of trophobiosis between ants and Heteroptera. C.R. Acad. Sci. Paris, Sciences de la Vie 323: 447-454.

Dejean, A., P.R. Ngnegueu \& T. Bourgoin. 1996. Trophobiosis between ants and Peregrinus maidis (Hemiptera, Fulgoromorpha, Delphacidae). Sociobiology 28: 111-120.

Dejean, A. \& R. Mony. 1991. Attaques d'arbres fruitiers tropicaux par les fourmis du genre Melissotarsus (Emery) (Hymenoptera, Formicidae) associées aux Homoptères Diaspididae. Actes Coll. Insectes Soc. 7: 179-187.

Dejean, A. \& T. Bourgoin. 1998. Relationships between ants (Hymenoptera : Formicidae) and Euphyonarthex phyllostoma (Hemiptera: Tettigometridae). Sociobiology 32: 91-100.

Dejean, A., T. Bourgoin \& J. Orivel. 2000b. Ant defense of Euphyonarthex phyllostoma (Homoptera: Tettigometridae) during trophobiotic associations. Biotropica 32: 112-119.

Dejean, A., T. Bourgoin \& M. Gibernau. 1997. Ant species that protect figs against other ants: result of territoriality induced by a mutualistic homopteran. Ecoscience 4: 446453.

Delabie, J.H.C. 1990. The ant problems of cocoa farms in Brazil, p. 555-569. In R.K. Vander Meer, K. Jaffe \& A. Cedeño (eds.), Applied Myrmecology: A world 
perspective, Westview Press, Boulder, Colorado, USA, $741 \mathrm{p}$.

Delabie, J.H.C., A.M. Encarnação \& I.C. Maurício. 1994. Relations between the little fire ant, Wasmannia auropunctata, and its associated mealybug, Planococcus citri, in Brazilian cocoa farms, p. 91-103. In D F Williams (ed.), Exotic ants: biology, impact and control of introduced species, Westview Press, Boulder, Colorado (U.S.A.), 333p.

Delabie, J.H.C., J.E. Mantovani \& I.C. Mauricio. 1990. Observações sobre a biologia de duas espécies de Acropyga (Formicidae, Formicinae, Plagiolepidini) associadas a rizosfera do cacaueiro. Rev. Brasil. Biol. 51: 185-192.

Delage-Darchen, B., D. Matile-Ferrero \& A.S. Balachowsky. 1972. Sur un cas aberrant de symbiose cochenilles x fourmis. C.R. Acad. Sc. Paris, série D, 275: 2359-2361.

DeVries, P.J. 1991. Evolutionary and ecological patterns in myrmecophilous riodinid butterflies, p. 143-156. In C.R. Huxley \& D.F. Cutler (eds), Ant-plant interactions. Oxford University Press, Oxford, 601p.

Dietrich, C.H. \& S.H. McKamey. 1990. Three new idiocerine leafhopper (Homoptera: Cicadellidae) from Guyana with notes on ant-mutualism and subsociality. Proc. Entomol. Soc. Wash. 92: 214-223.

Dolling, W.R. 1991. The Hemiptera. Oxford University Press, Oxford, 274p.

Dorow, W.H.O. \& U. Maschwitz. 1990. The arachne-group of Polyrhachis (Formicidae, Formicinae): weaver ants cultivating Homoptera on bamboo. Insectes Soc. 37: 73-89.

Douglas, A.E. 1998. Nutritional interactions in insectmicrobial symbioses: aphids and their symbiotic bacteria Buchnera. Annu. Rev. Entomol. 43:17-37.

Dufour, B. 1991. Place et importance des différentes espèces d'insectes dans l'écologie du CSSV (Cocoa Swollen Shoot Virus) au Togo. Café Cacao Thé 35: 197-204.

Dumpert, K., U. Maschwitz, W. Nassig \& W. Dorow. 1989. Camponotus (Karavaievia) sp.n. and C. (K.) montanus sp.n., two weaver ant species from Malaysia (Formicidae: Formicinae). Zool. Beitr. N.F. 32: 217-231.

Evans, H.C. 1963. The phylogeny of the Homoptera. Annu. Rev. Entomol. 8: 77-94.

Evans, H.C. \& D. Leston. 1971. A Ponerine ant (Hym., Formicidae) associated with Homoptera on cocoa in Ghana. Bull. Entomol. Res. 61: 357-362.

Fisher, B.L. \& H.G. Robertson. 1999. Silk production by adult workers of the ant Melissotarsus emeryi (Hymenoptera, Formicidae) in South African fynbos. Insectes Soc. 46: 78-83.

Flanders, S.E. 1957. The complete interdependence of an ant and a coccid. Ecology 38: 535-536.

Flatt, T. \& W.W. Weisser. 2000. The effects of mutualistic ants on aphid life history traits. Ecology 81: 3522-3529.

Floate, K.D. \& T.G. Whitham. 1994. Aphid-ant interaction reduces chrysomelid herbivory in a cottonwood hybrid zone. Oecologia 97: 215-221.

Fowler, H.G., L.C. Forti, C.R.F. Brandão, J.H.C. Delabie \& H.L. Vasconcelos. 1991. Ecologia nutricional de formigas, p. 131-223. In A.R. Panizzi e J.R.P. Parra (eds.), Ecologia nutricional de insetos e suas implicações no manejo de pragas, Editora Manole e CNPq, São Paulo, $359 \mathrm{p}$.

Gaume, L., D. Matile-Ferrero \& D. McKey. 2000. Colony foundation and acquisition of coccoid trophobionts by Aphomomyrmex afer (Formicinae): co-dispersal of queens and phoretic mealybugs in an ant-planthomopteran mutualism ? Insectes Soc. 47: 84-91.

Gaume, L., D. McKey \& S. Terrin. 1998. Ant-homopteran mutualism: how the third partner affects the interaction between a plant-specialist ant and its myrmecophyte host. Proc. R. Soc. London B, 265 : 569-575.

Gibernau, M. \& A. Dejean. 2001. Ant protection of a Heteropteran trophobiont against a parasitoid wasp. Oecologia 126: 53-57.

González-Hernández, H., N.J. Reimer \& M.W. Johnson. 1999. Survey of the natural enemies of Dysmicoccus mealybugs on pineapple in Hawai. BioControl 44: 4758.

Gullan, P.J. 1997. Relationships with ants, p. 351-377. In Y. Ben-Dov \& C.J. Hodgson (eds.), Soft scale insects - their biology, natural enemies and control, Elsevier Science, Amsterdam.

Gullan, P.J. \& M. Kosztarab. 1997. Adaptations in scale insects. Annu. Rev. Entomol. 42: 23-50.

Gullan, P.J., R.C. Buckley \& P.S. Ward. 1993. Ant-tended scale insects (Hemiptera: Cocccidae: Myzolecanium) within lowland rain forest trees in Papua New Guinea. J. Trop. Ecol. 9: 81-91.

Hackman, R. \& V.M. Trikojus. 1952. The composition of the honeydew excreted by Australian coccids of the genus Ceroplastes. Biochem. J. 51: 653-656.

Hayes, W.P. 1920. Solenopsis modesta Say (Hym.): a biological study. Agricultural Experiment Station, Kansas 
State Agriculture College, Manhattan, Kansas, Techn. Bull. 7, 54p.

Heckroth, H.-P., B. Fiala, P.J. Gulan, A.H.J. Idris \& U. Maschwitz. 1998. The soft scale (Coccidae) associates of Malaysian ant-plants. J. Trop. Ecol. 14: 427-443.

Hölldobler, B. \& E.O. Wilson. 1990. The ants. The Belknap Press of the Harvard University Press, Cambridge, Massachusetts, 732p.

Houk, E.J. \& G.W. Griffiths. 1980. Intracellular symbiotes of the Homoptera. Ann. Rev. Entomol. 25: 161-187.

Huang, H.T. \& P. Yang. 1987. The ancient cultured citrus ant - a tropical ant used to control insect pests in southern China. Biosci. 37: 665-671.

Jolivet, P. 1996. Ants and plants, an example of coevolution (enlarged edition). Backhuys Publishers, Leiden, 303p.

Johnson, C., D. Agosti, J.H. Delabie, K. Dumpert, D.J. Williams, M. von Tschirnhaus \& U. Maschwitz. 2001. Acropyga and Azteca ants (Hymenoptera: Formicidae) with scale insects (Sternorrhyncha: Coccoidea): 20 million years of intimate symbiosis. Am. Mus. Novitates 3335: $18 \mathrm{p}$.

Karasev, A.V. 2000. Genetic diversity and evolution of closteroviruses. Annu. Rev. Phytopathol. 38: 293-324.

Kirkpatrick, T.W. 1952. Notes no minor insect pests of cacao in Trinidad. A report of cacao research, The Imperial College of Tropical Agriculture, St Augustine, Trinidad, B.W.I., 62-71.

Klein, R.W., D. Kovac, A. Schellerich \& U. Machwitz. 1992. Mealybug-carrying by swarming queens of a Southeast Asian bamboo-inhabiting ant. Naturwissenschaften 79: 422-423.

Kosztarab, M. 1987. Everything unique or unusual about scale insects (Homoptera : Coccoidae). Bull. Entomol. Soc. Am. 33: 215-220.

Lambdin, P. \& M. Kosztarab. 1988. Psoraleococcus browni: a new species of pit scale from Papua New Guinea (Homoptera : Coccoidea : Lecanodiaspididae). Ann. Entomol. Soc. Am. 81: 724-727.

Larsen, K.J., F.E. Vega, G. Moya-Raygoza \& L.R. Nault. 1991. Ants (Hymenoptera: Formicidae) associated with the leafhopper Dalbulus quinquenotatus (Homoptera: Cicadellidae) on gamagrasses in Mexico. Ann. Entomol. Soc. Am. 84: 498-501.

Larsen, K.J., S.E. Heady \& L.R. Nault. 1992. Influence of ants (Hymenoptera: Formicidae) on honeydew excretion and escape behaviors in a myrmecophile, Dalbulus quinquenotatus (Homoptera: Cicadellidae), and its congeners. J. Insect Behav. 5: 109-122.

Liefke, C., W.H.O. Dorow, B. Hölldobler \& U. Maschwitz. 1998. Nesting and food resources of syntopic species of the ant genus Polyrhachis (Hymenoptera, Formicidae) in West-Malaysia. Insectes Soc. 45: 411-425.

Liepert, C. \& K. Dettner. 1993. Recognition of aphid parasitoids by honeydew-collecting ants: the role of cuticular lipids in a chemical mimicry system. J. Chem. Ecol. 19: 2143-2153.

Majer, J.D. 1993. Comparison of the arboreal ant mosaic in Ghana, Brazil, Papua New Guinea and Australia its structure and influence on arthropod diversity, 115141. In J. LaSalle \& I.D. Gault (eds.), Hymenoptera and biodiversity, CAB International, Wallingford, UK, $348 \mathrm{p}$.

Malsch, A.K.F., E. Kaufmann, H.-P. Heckroth, D.J. Williams, M. Maryati \& U. Maschwitz. (in press). Continuous transfer of subterranean mealybugs (Hemiptera, Pseudococcidae) by Pseudolasius spp. (Hymenoptera, Formicidae) during colony fission. Insectes Soc.

Maschwitz, U. \& B. Fiala. 1995. Investigations on ant-plant associations in the South-East-Asian genus Neonauclea Merr. (Rubiaceae). Acta Oecologica 16: 3-18.

Maschwitz, U., B. Fiala, S.J. Davies \& K.E. Linsenmair. 1996. A South-East Asian myrmecophyte with two alternative inhabitants: Camponotus or Crematogaster as partners of Macaranga lamellata. Ecotropica 2: 2940.

Maschwitz, U., B. Fiala \& W.R. Dolling. 1987. New trophobiotic symbioses of ants with South East Asian bugs. J. Nat. Hist. 21 : 1097-1107.

Maschwitz, U. \& H. Hänel. 1985. The migrating herdsman Dolichoderus (Diabolus) cuspidatus: an ant with a novel mode of life. Behav. Ecol. Sociobiol. 17: 171-184.

Maschwitz, U., K. Dumpert \& K.R. Tuck. 1986. Ants feeding on anal exudate from tortricid larvae: a new type of trophobiosis. J. Nat. Hist. 20 : 1041-1050.

Maschwitz, U. \& M. Dill. 1998. Migrating herdsmen of Mount Kinabalu. Borneo 4: 32-41.

Maschwitz, U., W.H.O. Dorow, A.L. Schellerich-Kaaden, A. Buschinger \& H.I. Azarae. 2000. Cataulacus muticus Emery 1889 a new case of a Southeast arboreal ant- non-mutualistically specialized on giant bamboo (Insecta, Hymenoptera, Formicidae, Myrmicinae). Senckenbergiana Boil. 80: 165-173.

Mattes, M., J. Moog, M. Werner, B. Fiala, J. Nais \& U. Maschwitz. 1998. The rattan palm Korthalsia robusta 
B1. and its ant and aphid partners: studies of a myrmecophytic association in the Kinabalu Park. Sabah Parks Nature J. 1: 47-60.

McKey, D. \& L. Meunier. 1996. Évolution des mutualismes plantes-fourmis - quelques éléments de réflexion. Actes Coll. Insectes Sociaux 10: 1-9.

Miller, D.R. \& M. Kosztarab. 1979. Recent advances in the study of scale insects. Annu. Rev. Entomol. 24: 1-27

Morales, M.A. 2000. Mechanisms and density dependence of benefit in an ant-membracud mutualism. Ecology 81: 482-489.

Moya-Raygoza, G. \& L.R. Nault. 2000. Obligatory mutualism between Dalbulus quinquenotatus (Homoptera: Cicadellidae) and attendant ants. Ann. Entomol. Soc. Am. 93: 929-940.

Myers, J.G. 1928. Insects exploiters of animal secretions. A chapter of animal behaviour. Bull. Brooklyn Entomol. Soc. 23: 157-173.

Myers, J.G. 1929. Observations on the biology of two remarkable cixiid plant-hoppers (Homoptera) from Cuba. Psyche 34: 283-292.

Nechols, J.R. \& T.F. Seibert. 1985. Biological control of the spherical mealybug, Nipaecoccus vastator (Homoptera: Pseudococcidae): assessment by ant exclusion. Environ. Entomol. 14: 45-47.

Nickerson, J.C., W.H. Whitcomb \& G.W. Dekle. 1974. Eriococcus smithi (Eriococcidae: Homoptera): a new species record for Florida. Fla. Entomol. 57: 285.

Nielsen, M.G. 1997. Two specialized ant species, Crematogaster (australis Mayr group) sp. and Polyrhachis sokolova Forel in Darwin Harbour mangroves. Northern Territory Nat. 15: 1-5.

Nixon, G.J. 1951. The association of ants with aphids and coccids. Commonwealth Institute of Entomology, London, 36p.

Oliveira, P.S. \& C.R.F. Brandão. 1991. The ant community associated with extrafloral nectaries in the Brazilian cerrados, p. 198-212. In C.R. Huxley \& D.F. Cutler (eds), Ant-plant interactions. Oxford University Press, Oxford, $601 \mathrm{p}$.

Oliveira, P.S. \& M.R. Pie. 1998. Interaction between ants and plants bearing extrafloral nectaries in cerrado vegetation. An. Soc. Entomol. Brasil 27: 161-176.

Ozaki, K, S. Takashima \& O. Suko. 2000. Ant predation suppresses populations of the scale insect Aulacaspis marina in natural mangrove forests. Biotropica 32: 764768.
Paulson, G.S. 1998. Population ecology of Formica neoclara (Emery) (Hymenoptera: Formicidae) and its possible role in the biological control of pear psylla, Cacopsylla pyricola (Foerster) (Homoptera : Psyllidae). Recent Res. Develop. Entomol. 2: 113-124.

Perfecto I. \& A. Sediles. 1992. Vegetational diversity, ants (Hymenoptera: Formicidae), and herbivorous pests in a Neotropical agroecosystem. Environ. Entomol. 21 : 61-67.

Pesson, P. 1944. Contribution à l'étude morphologique et fonctionnelle de la tête, de l'appareil buccal et du tube digestif des femelles de coccides. Ministère de l'Agriculture et du Ravitaillement, Imprimerie Nationale, Paris, 260p.

Pierce, N.E., D.R. Nash, M. Baylis \& E.R. Carper. 1991. Variation in the attractiveness of lycaenid butterfly larvae to ants, p. 131-142. In C.R. Huxley \& D.F. Cutler (eds), Antplant interactions. Oxford University Press, Oxford, 601p.

Prins, A.J., Y. Ben-Dov \& D.J. Rust. 1975. A new observation on the association between ants (Hymenoptera: Formicidae) and armoured scale insects (Homoptera: Diaspidiae). J. Entomol. Soc. South. Afr. 38: 211-216.

Rico-Gray, V. 1993. Use of plant-derived food resources by ants in the dry tropical lowlands of coastal Veracruz, Mexico. Biotropica 25: 301-315.

Rozario, S.A., R.A. Farrow \& P.J. Gullan. 1993. Effects of ant attendance on reproduction and survival of Eurmeloides punctata (Signoret) and Eurymela distincta Signoret (Hemiptera: Eurymelidae) on eucalypts. J. Aust. Entomol. Soc. 32: 177-186.

Sakata, H. 1994. How an ant decides to prey on or to attend aphids. Res. Popul. Ecol. 36: 45-51.

Sakata, H. 1995. Density-dependent predation of the ant Lasius niger (Hymenoptera: Formicidae) on two attended aphids Lachnus tropicalis and Myzocallis kuricola (Homoptera: Aphididae). Res. Popul. Ecol. 37: 159-164.

Sakata, H. \& Y. Hashimoto. 2000. Should aphids attract or repel ants? Effect of rival aphids and extrafloral nectarines on ant-aphid interactions. Res. Popul. Ecol. 42: $171-178$.

Samways, M.J. 1983. Interrelationship between an entomogenous fungus and two ant-homopteran (Hymenoptera: Formicidae - Homoptera: Pseudococcidae \& Aphididae) mutualisms on guava trees. Bull. Entomol. Res. 73: 321-331.

Schultz, T.R. \& T.P. McGlynn. 2000. The interactions of ants with other organisms, p. 35-44. In D. Agosti, J.D. Majer, L. Tennant de Alonso \& T. Schultz (eds), Ants: standart methods for measuring and monitoring 
biodiversity, Smithsonian Institution, Washington, 280p.

Schütze, M. \& U. Maschwitz. 1991. Enemy recognition and defense within trophobiotic associations with ants by the soldier caste of Pseudoregma sundanica (Homoptera: Aphidoidea). Entomol. Gener. 16: 1-12.

Seibert, T.F. 1992. Mutualistic interactions of the aphid Lachnus allegheniensis (Homoptera : Aphididae) and its tending ant Formica obscuripes (Hymenoptera: Formicidae). Ann. Entomol. Soc. Am. 85: 173-178.

Seifert, B. 1996. Ameisen: beobachten, bestimmen. Naturbuch Verlag, Augsburg, 351p.

Skinner, G.J. \& J.B.Whittaker. 1981. An experimental investigation of inter-relationships between the woodant (Formica rufa) and some tree-canopy herbivores. J. An. Ecol. 50: 313-326.

Soares, I.M.F. \& J.H.C. Delabie. 1999. Influência da população de formigas (Hymenoptera: Formicidae) sobre a população de cochonilhas da "palma" forrageira, Diaspis echinocacti (Bouché, 1833) (Hemiptera: Diaspididae). Naturalia 24: 141-142.

Stadler, B. \& A.F.G. Dixon. 1998a. Costs of ant attendance for aphids. J. An. Ecol. 67: 454-459.

Stadler, B. \& A.F.G. Dixon. 1998b. Why are obligate mutualistic interactions between aphids and ants so rare?, p. 271-278. In J.M. Nieto Nafria \& A.F.G. Dixon (eds.), Aphids in natural and managed ecosystems, Universidad de León, León, Spain.

Stadler, B. \& A.F.G. Dixon. 1999. Ant attendance in aphids: why different degrees of myrmecophily? Ecol. Entomol. 24: 363-369.

Stadler, B., K. Fiedler, T.J. Kawecki \& W.W. Weisser. 2001. Costs and benefits for phytophagous myrmecophiles: when ants are not always available. Oikos 92: 476-478.

Stephens, G.R. \& D.E. Aylor. 1978. Aerial dispersal of red pine scale, Matsucoccus resinosae (Homoptera: Margarodidae).Environ. Entomol. 7: 556-563.

Sudd, J.H. 1987. Ant aphid mutualism, 355-365. In A.K. Minks \& P. Harrewijn (eds.), Aphids, their biology, natural ennemies, and control. vol. 2A, World Crop Pests, Elsevier, Amsterdam.

Sullivan, D.J. \& W. Völk. 1999. Hyperparasitism: multitrophic ecology and behavior. Annu. Rev. Entomol. 44: 291-315.
Tilles, D.A. \& D.L. Wood. 1982. The influence of Carpenter ant (Camponotus modoc) (Hymenoptera: Formicidae) attendance on the development and survival of aphids (c=Cinara spp.) (Homoptera: Aphididae) in a giant sequoia forest. Can. Entomol. 114: 1133-1142.

Vinson, S.B. \& T.A. Scarborough. 1991. Interactions between Solenopsis invicta (Hymenoptera: Formicidae), Rhopalosiphum maidis (Homoptera: Aphididae), and the parasitoid Lysiphlebus testaceipes Cresson (Hymenoptera: Aphidiidae). Ann. Entomol. Soc. Am. 84: $158-164$.

Washburn J.O. \& L. Washburn. 1983. Active aerial dispersal of minute wingless arthropods: exploitation of boundarylayer velocity gradients. Science 223: 1088-1089.

Way, M.J. 1954. Studies on the association of the ant Oecophylla longinoda (Latr.) (Formicidae) with the scale insect Saissetia zanzibarensis Williams (Coccidae). Bull. Entomol. Res. 113-136.

Way, M.J. 1963. Mutualism between ants and honeydewproducing Homoptera. Annu. Rev. Entomol. 8: 307-344.

Way, M.J. \& K.C. Khoo. 1992. Role of ants in pest management. Annu. Rev. Entomol. 37: 479-503.

Weber, N.A. 1944. The Neotropical coccid-tending ants of the genus Acropyga Roger. Ann. Entomol. Soc. Am. 37: $89-122$.

Weber, N.A. 1946. Two common ponerine ants of possible economic significance, Ectatomma tuberculatum (Olivier) and E. ruidum Roger. Proc. Entomol. Soc. Wash. 48: 1-16.

Wheeler, W.M. 1914. The ants of the Baltic amber. Schriften der Phys.-Ökon. Ges. Königsberg 55: 1142.

Williams, D.J. 1998. Mealybugs of the genera Eumyrmococcus Silvestri and Xenococcus Silvestri associated with the ant genus Acropyga Roger and a review of the subfamily Rhizoecinae (Hemiptera, Coccoidea, Pseudococcidae). Bull. Nat. Hist. Mus. London 67: 1-64.

Wimp, G.M. \& T.G. Whitham. 2001. Biodiversity consequences of predation and host plant hybridization on an aphid-ant mutualism. Ecology 82: 440-452.

Wood, T.K. 1982. Seletive factors associated with the evolution of membracid sociality, p. 175-178. In M.D. Breed, C.D. Michener \& H.E. Evans (eds.), The biology of social insects, Westview Press, Boulder, Colorado, USA. 